\title{
Development and evaluation of reverse transcription-loop-mediated isothermal amplification assay for rapid detection of enterovirus 71
}

Weifeng Shi ${ }^{1 *}$, Kun $\mathrm{Li}^{1}$, Yun $\mathrm{Ji}^{1}$, Qingbo Jiang ${ }^{1}$, Mei Shi ${ }^{1}$ and Zuhuang $\mathrm{Mi}^{2}$

\begin{abstract}
Background: Hand, foot, and mouth disease (HFMD) caused by enterovirus 71 (EV71) is very common in China. It is difficult to distinguish between EV71 and coxsackievirus A16 (CVA16) infections in clinical HFMD patients. Routine laboratory diagnosis of EV71 infection is time-consuming and requires expensive instruments. In this study, we have developed a one-step, single tube, reverse transcription-loop-mediated isothermal amplification (RT-LAMP) assay for rapid and sensitive detection of EV71.

Methods: Six primers that can recognize 6 distinct regions on the VP2 gene of EV71 were designed for RT-LAMP assay. The amplification was completed by incubating all reagents in a single tube with reverse transcriptase and Bst DNA polymerase under the isothermal condition $\left(60^{\circ} \mathrm{C}\right)$ for $60 \mathrm{~min}$, and could be evaluated by using GoldView staining under a handheld ultraviolet torch lamp or electrophoresis analysis.

Results: A total of 123 specimens collected from suspicious patients with HFMD were simultaneously detected by RT-LAMP and PCR fluorescence probing assay. The RT-LAMP amplified products containing EV71 were digested by Hinfl and Taql restriction endonucleases; in contrast, non-specific products with CVA16, coxsackievirus A4 and coxsackievirus B3 could not be detected in RT-LAMP assay. Meanwhile, RT-LAMP assay could amplify EV71 virus with a detection limit of 1 PFU/ml within 60 min. Compared with PCR fluorescence probing assay, RT-LAMP assay exhibited $98.4 \%$ identity during the detection of EV71 viral RNA without the missing of positive samples.

Conclusion: Our results indicated that RT-LAMP is a rapid, sensitive, specific and accurate method for the detection of EV71 in clinical specimens. Therefore, this developed method has potential application for rapid and comprehensive surveillance for EV71 infection, especially in developing country.
\end{abstract}

\section{Background}

HFMD, a common illness in children, can be caused by many human enteroviruses such as coxsackie viruses A4, A5, A6, A10, A16, B1, B3, and EV71 [1-4]. Among these viruses, human EV71 and CVA16 are major causative agents of HFMD. EV71 and CVA16 infections in HFMD are indistinguishable. However, EV71 infection is frequently associated with serious neurological complications and fatalities [5]. EV71 was initially isolated

\footnotetext{
* Correspondence: shiweifeng67@163.com

'Department of Clinical Laboratory, The Third Affiliated Hospital of Suzhou University, No. 185 Juqian street, Changzhou, Jiangsu 213003, P. R. China Full list of author information is available at the end of the article
}

from the stool of a 9-month-old infant with fatal encephalitis in California in 1969 [6]. Subsequently, the prevalence of EV71 infection has been reported in many countries and regions, such as Taiwan, Hongkong, Malaysia and Singapore, as well as Guangdong, Hunan, Jiangsu and Fuyang in China [7-13]. EV71 and CVA16 infections mainly occurred in children under 5 years old. However, patients infected with EV71 are liable to cause aseptic meningitis, encephalomyelitis, and pulmonary edema $[14,15]$.

Traditional EV71 infection is primarily dependent on serodiagnosis, and virus culture and identification. However, these methods are time-consuming and easy to

\section{Biomed Central}

(c) 2011 Shi et al; licensee BioMed Central Ltd. This is an Open Access article distributed under the terms of the Creative Commons Attribution License (http://creativecommons.org/licenses/by/2.0), which permits unrestricted use, distribution, and reproduction in any medium, provided the original work is properly cited. 
produce cross-immune response with CVA16. Recently, reverse transcription-PCR (RT-PCR) and real-time PCR assays have been used for EV71 detection [16-18]. These nucleic acid amplification methods with intrinsic disadvantages of requiring sophisticated instrumentations and expensive reagents may not be the best choice for basic clinical settings in developing countries or in field situations. Therefore, it is necessary to develop a rapid, reliable, and simple molecular test to take the place of existing techniques. In 2000, a newly developed LAMP method with the characteristics of simplicity, rapidity, specificity, and cost-effectiveness has the potential to replace PCR [19]. LAMP is based on the principle of strand displacement reaction so that the stem-loop structure can amplify the target with high specificity, selectivity and rapidity under isothermal conditions. LAMP can also produce a large amount of target DNA and by-product magnesium pyrophosphate for the formation of turbidity. Therefore, LAMP assays have been widely used to detect a variety of infectious diseases, such as bacterial, fungus and viral infections [20-22].

Nowadays, the application of LAMP method in EV71 detection was less reported [23]. In the present study, we have developed a one-step, single-tube, and real-time RT-LAMP assay to detect EV71. The amplified products can be stained by double-stranded DNA binding fluorescent dye (GoldView stain), and observed through naked eyes under the UV lamp. Compared with PCR fluorescence probing assay, RT-LAMP had high sensitivity and specificity during EV71 detection, which is suitable for the application in primary health care agencies.

\section{Methods}

\section{Specimen collection}

A total of 123 suspicious patients with HFMD under 5 years old were enrolled in 2009 in Changzhou, China. This study was approved by the local ethics committee and all patients were provided a written informed consent. Totally 93 pharyngeal swabs, 20 vesicular fluid swabs and 10 fecal samples were collected from these patients within 4 days after the onset of infection, and stored in 3-5 $\mathrm{ml}$ of preservation solution (Hanks solution containing $10 \mu \mathrm{g} / \mathrm{ml}$ gentamicin and $0.25 \mu \mathrm{g} / \mathrm{ml}$ amphotericin B) at $-70^{\circ} \mathrm{C}$ for analysis.

\section{Virus isolation and identification}

Specimens were inoculated into rhabdomyosarcoma (RD) cells for the isolation of EV71. Enterovirus strains were identified by using immunofluorescence test with EV71 monoclonal antibody (Chemicon International Inc.).

\section{Primer design for RT-LAMP}

Six primers were designed according to the VP2 gene sequences of EV71 virus published in GenBank (accession No. AY465356), and was aligned with available VP2 gene sequences of other strains, including the circulating strains in China responsible for recent epidemics, to identify the conserved regions using DNASIS software. The potential target region of $194 \mathrm{bp}$ corresponding to the genome positions from 1296 to 1489 was selected from the aligned sequences, including two inner, two outer primers and two loop primers (Figure 1). Two inner primers were called the forward inner primer (FIP) and the backward inner primer (BIP), which contained two distinct sequences corresponding to the sense and antisense sequences of the target DNA, for priming in the first stage and self-priming in later stage, respectively. FIP contained the sequence (F1c) complementary to $\mathrm{F} 1$ and $\mathrm{F} 2$. BIP contained $\mathrm{B} 1$ and the sequence (B2c) complementary to B2. Two outer primers were composed of F3 and the sequence (B3c) complementary to B3 (Table 1).

\section{Extraction of viral RNA}

Prior to RNA extraction, fecal samples were treated with chloroform according to the protocol described

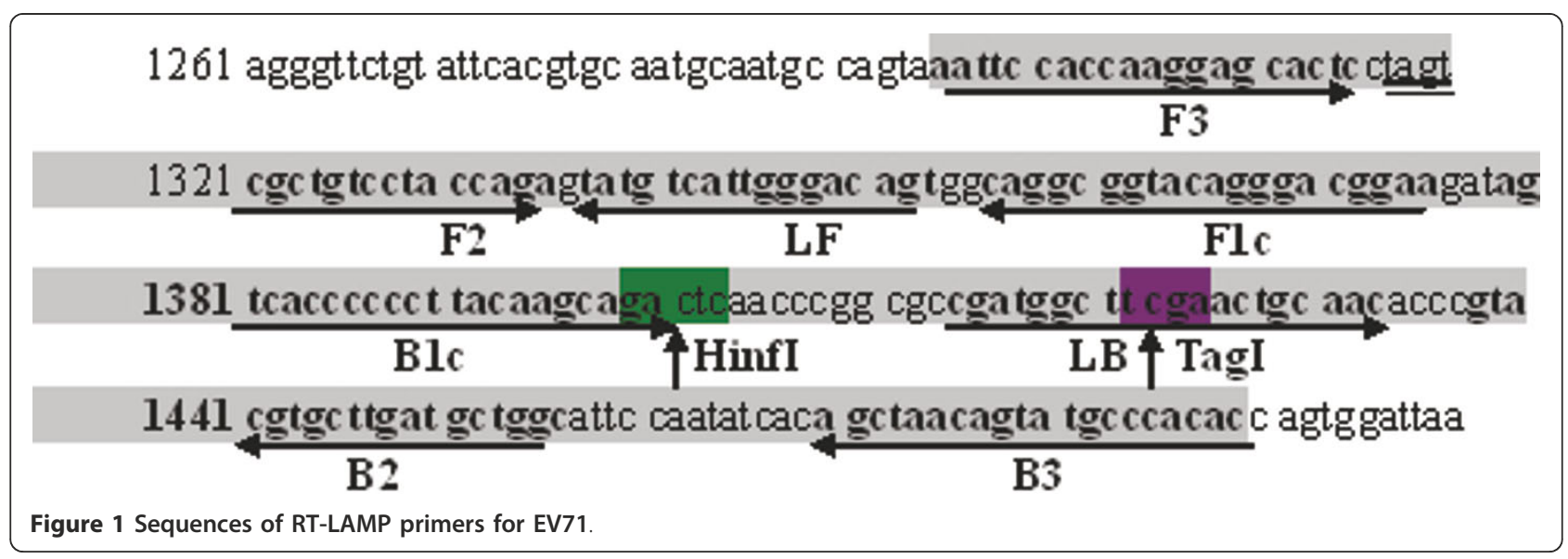


Table 1 The RT-LAMP primers

\begin{tabular}{ccr}
\hline Primer names & Length of oligonucleotides $(\mathbf{b p})$ & Primer sequences \\
\hline F3 & 20 & 5'-AATTCCACCAAGGAGCACTC-3' $^{\prime}$ \\
\hline B3 & 20 & $5^{\prime}$-GTGTGGGCATACTGTTAGCT-3' \\
\hline FIP & 40 & 5'-TTCCGTCCCTGTACCGCCTGCTAGTCGCTGTCCTACCAGA-3' $^{\prime}$ \\
\hline BIP & 40 & 5'-GTCACCCCCCTAACAAGCAGAGCCAGCATCAAGCACGTAC-3' $^{\prime}$ \\
\hline LF & 17 & 5'-ACTGTCCCAATGACATA-3' \\
\hline LB & 20 & \\
\hline
\end{tabular}

elsewhere [24]. The genomic viral RNA was extracted from $100 \mu \mathrm{l}$ of swab specimens or pretreated feces by using the QIAamp viral RNA extraction kit (Qiagen, Germany) according to the manufacturer's instructions. The RNA was eluted from the QIAspin columns in a final volume of $100 \mu \mathrm{l}$ of elution buffer and kept at $-70^{\circ}$ $\mathrm{C}$ until further analysis.

\section{Reaction system of RT-LAMP}

The RT-LAMP reaction was performed in a $25 \mu \mathrm{l}$ of reaction mixture containing $0.8 \mu \mathrm{M}$ (each) FIP and BIP inner primers, $0.2 \mu \mathrm{M}$ forward outer primer (F3) and backward outer primer (B3), 0.4 $\mu \mathrm{M}$ LF and LB (each), 0.4 mM deoxynucleoside triphosphates (dNTPs), $1 \mathrm{M}$ betaine (Sigma, USA), $20 \mathrm{mM}$ Tris- $\mathrm{HCl}$ $(\mathrm{pH} 8.8), 10 \mathrm{mM} \mathrm{KCl}, 10 \mathrm{mM}\left(\mathrm{NH}_{4}\right)_{2} \mathrm{SO}_{4}, 2.8 \mathrm{mM}$ $\mathrm{MgSO}_{4}, 0.1 \%$ Triton X-100, $0.5 \mu \mathrm{l}$ of $8 \mathrm{U}$ Bst DNA polymerase (New England Biolabs, USA), $40 \mathrm{U}$ of reverse transcriptase (Invitrogen), and $5 \mu$ l of target RNA. Six temperatures $\left(60,61,62,63,64\right.$ and $\left.65^{\circ} \mathrm{C}\right)$ were screened during RT-LAMP assay, and finally the optimal temperature was monitored by agarose gel electrophoresis. Amplification was completed in PCR microtubes in an electric thermostatic water bath (Suopu, Shanghai, China) at the isothermal condition of $60^{\circ} \mathrm{C}$ for $60 \mathrm{~min}$. GoldView dye (Sbsgene, China) was used to evaluate the reaction system with the reference of a negative control and a positive control. The samples with fluorescence change from orange to red or from orange to green were considered as the negative and positive reactions under ultraviolet (UV) light (254 nm) with a handheld lamp.

\section{PCR fluorescence probing assay and nucleotide sequencing}

The PCR fluorescence probing assay reagent (DaAn Gene, China) was commercially available. The cDNA was generated in a $20 \mu \mathrm{l}$ of reaction volume for $25 \mathrm{~min}$ at $40^{\circ} \mathrm{C}$ using random primers and SuperScript II reverse transcriptase (Invitrogen) according to the instructions. The cycling conditions were composed of 5 min at $94^{\circ} \mathrm{C}$, followed by 40 cycles with $93^{\circ} \mathrm{C}$ for $15 \mathrm{~s}$, $55^{\circ} \mathrm{C}$ for $45 \mathrm{~s}$, and $72^{\circ} \mathrm{C}$ for $1 \mathrm{~min}$, and a final extension cycle of $72^{\circ} \mathrm{C}$ for $10 \mathrm{~min}$. The PCR products were examined by Lighter cycler (Roche, Germany). Forward primer EV71-F: 5'-AAA GGT GGA GCT GTT CAC CTA CAT GCG CTT TGA C-3', reverse primer EV71-R: 5'AAT CTG GCT TGG GGG CCC CAG GTG GTA CAA-3', and oligonucleotide probe EV71-P: 5' -CCC ACC GGG GAA GTT GTC CCA CAA TTG CTC C-3'. The specific oligonucleotide probes were added, and the results were considered as the positive for $\mathrm{Ct}$ value not higher than 35.1. All amplicons were sequenced with an ABI 3730 automated DNA sequencer (Applied Biosystems).

\section{Specificity of RT-LAMP assay}

A restriction analysis by using HinfI or TaqI endonuclease was used to validate the specificity of EV71 amplification reaction. Enzymatic reaction system is composed as follows: $2 \mu \mathrm{l}$ of RT-LAMP product, $15 \mu \mathrm{l}$ of $\mathrm{ddH}_{2} \mathrm{O}, 1 \mu \mathrm{l}$ of $10 \times$ buffer $\mathrm{R}, 1 \mu \mathrm{l}$ of HinfI or TaqI for $10 \mathrm{U} / \mu \mathrm{l}$ (each). The digestion reactions of HinfI or TaqI were incubated at $37^{\circ} \mathrm{C}$ and $65^{\circ} \mathrm{C}$ for $2 \mathrm{~h}$, respectively. Finally, $1.5 \mu \mathrm{l}$ of digested RT-LAMP products were analyzed by agarose gel electrophoresis. Four virus strains of EV71, CVA16, coxsackievirus A4 (CVA4), and coxsackievirus B3 (CVB3) were provided by China Center for Type Culture Collection and Changzhou Center for Disease Control, respectively.

\section{Sensitivity of RT-LAMP and PCR fluorescence probing assay}

The EV71 or CVA16 was propagated in RD cells, and the titer was determined by plaque assay in vero cells $[25,26]$. Totally $0.5 \mathrm{ml}$ virus culture at various concentrations ranging from $10^{5}$ to $0.1 \mathrm{PFU} / \mathrm{ml}$ in a serial 10 fold dilution pattern was detected by RT-LAMP and PCR fluorescence probing assay. The products of RTLAMP were detected by agarose gel electrophoresis.

EV71 detection in clinical specimens by RT-LAMP and PCR fluorescence probing assay

Totally 93 pharyngeal swabs, 20 vesicular fluid swabs and 10 fecal samples with suspicious EV71 infection were extracted as described above and analyzed by RT- 
LAMP and PCR fluorescence probing assays with the reference of negative and positive control reactions containing CVA16 and EV71.

\section{Statistical analysis}

Statistically significant analysis of the clinical study was evaluated by using chi-square test. A significant difference was considered at the $P$ value of less than 0.05 .

\section{Results}

\section{The optimum reaction system of RT-LAMP assay}

The optimal temperature for RT-LAMP reaction was determined to be $60^{\circ} \mathrm{C}$, which could provide the optimal activity of Bst DNA polymerase (Figure 2A). Similarly, the optimal reaction time and concentrations of magnesium and betaine were identified as $60 \mathrm{~min}, 2.8 \mathrm{mM}$ and $1 \mathrm{M}$, respectively (Figure 2B, C and 2D). Under the GoldView staining, positive samples revealed the fluorescence change from orange to green (Figure 3).

\section{Restriction enzyme analysis of RT-LAMP products}

The specificity of RT-LAMP was confirmed by the digestion using Hinfl and TaqI restriction enzymes. The amplified products with EV71 resulted in a series of bands in agarose gel electropherosis. In contrast, nonspecific products with CVA16, CVA4 and CVB3 in RTLAMP assay could not be detected (Figure 4).

\section{Sensitivity of EV71 virus by RT-LAMP amplification}

The sensitivity of RT-LAMP and PCR fluorescence probing assay for the detection of EV71 RNA was evaluated by testing serial 10 -fold dilutions of virus through previously described as plaque assay. The RT-LAMP assay was able to amplify a small amount of virus in 60 min with a detection limit of $1 \mathrm{PFU} / \mathrm{ml}$ of virus (Figure 5A and 5B). RT-LAMP revealed 100-fold higher sensitivity than PCR fluorescence probing assay, which had a detection limit of 100 PFU (copy)/ml of virus (Figure 6).

\section{Detection of 123 clinical specimens}

In order to assess the diagnostic accuracy for suspicious patients with EV71 infection, 123 specimens were subjected to RT-LAMP assay with the parallel analysis by PCR fluorescence probing assay. The amplicons were sequenced. As shown in Table 2, an overall similarity between two test systems was $98.4 \%$ ( $P$ $>0.05$ ). No samples with positive reaction detected by PCR fluorescence probing assay was missed during
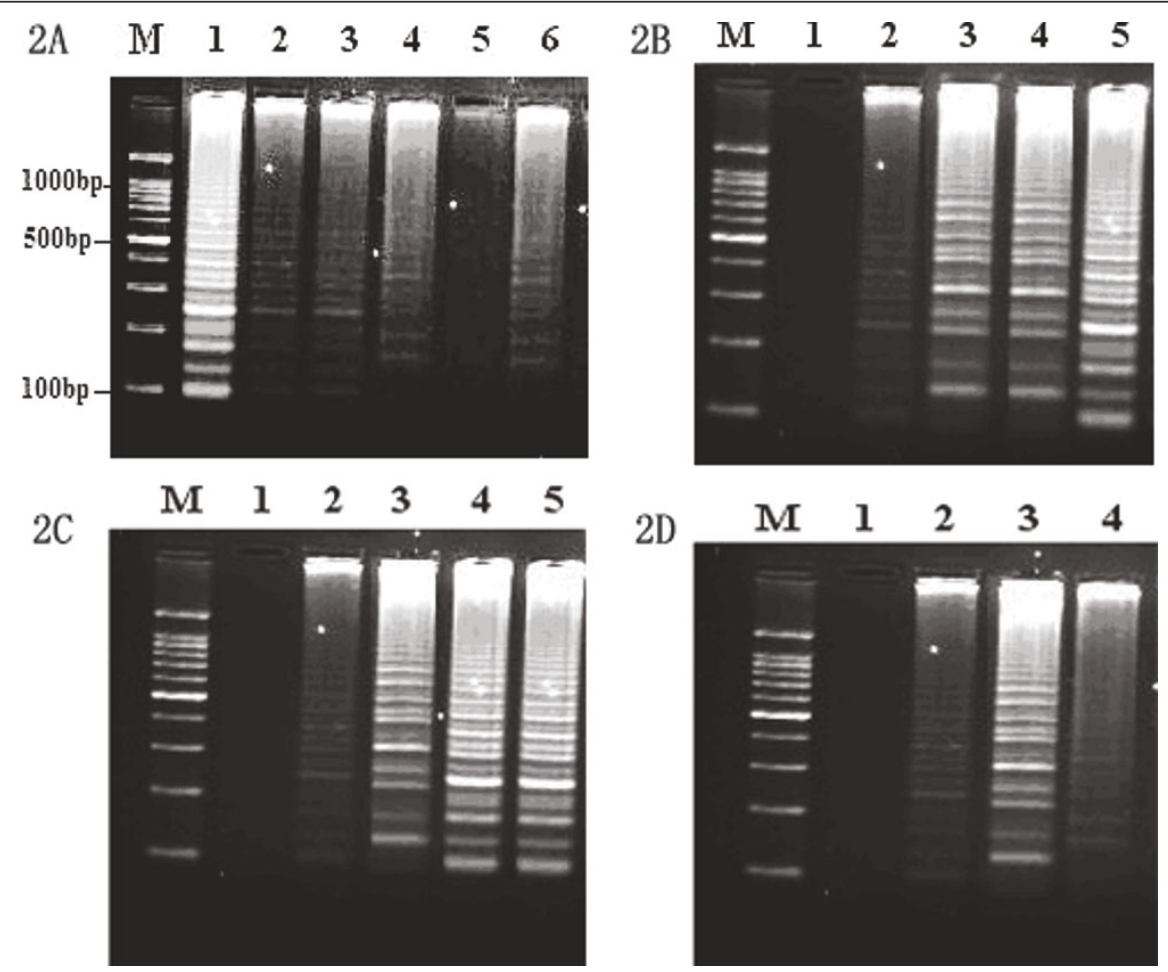

Figure 2 The optimal condition of RT-LAMP for the detection of EV71. (2A) The optimal temperature of RT-LAMP assay is monitored by agarose gel analysis. M: Marker, 100-bp DNA ladder (Sigma, USA); Lanes 1-6 are reaction temperatures at 60, 61, 62, 63,64 and $65^{\circ} \mathrm{C}$, respectively. (2B) The reaction time of RT-LAMP. Lanes 1-5 are reaction time of 30,40,50,60 and 70 min, respectively. (2C) The concentration of magnesium. Lanes 1-5 are magnesium at the concentrations of $0,1,2,2.8$ and $3.6 \mathrm{mM}$, respectively. (2D) The concentration of betaine. Lanes 1-4 are the betaine concentrations of $0,0.5,1.0$ and $1.5 \mathrm{M}$, respectively. 


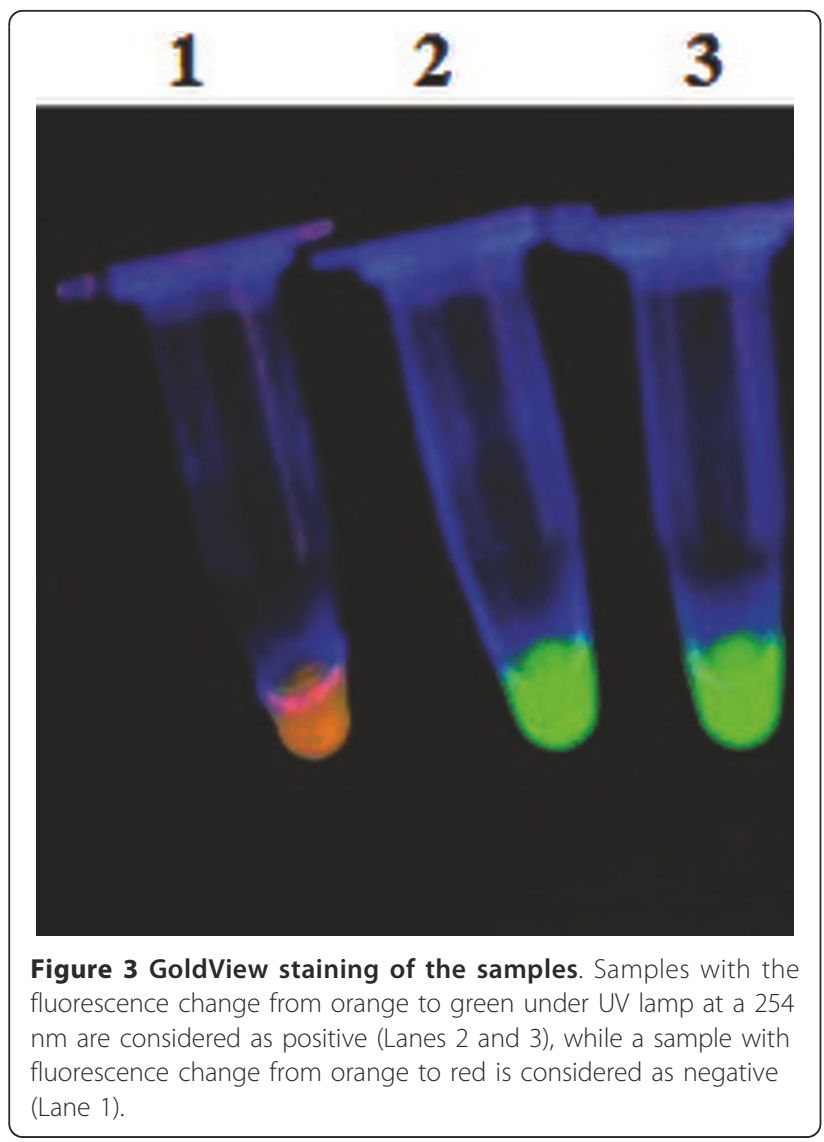

RT-LAMP assay, thereby indicating the superior sensitivity of RT-LAMP. Two positive samples detected by RT-LAMP assay but PCR fluorescence probing assay negative were then inoculated into RD cells and the positive culture was identified by indirect immunofluorescence test; however, only one sample was

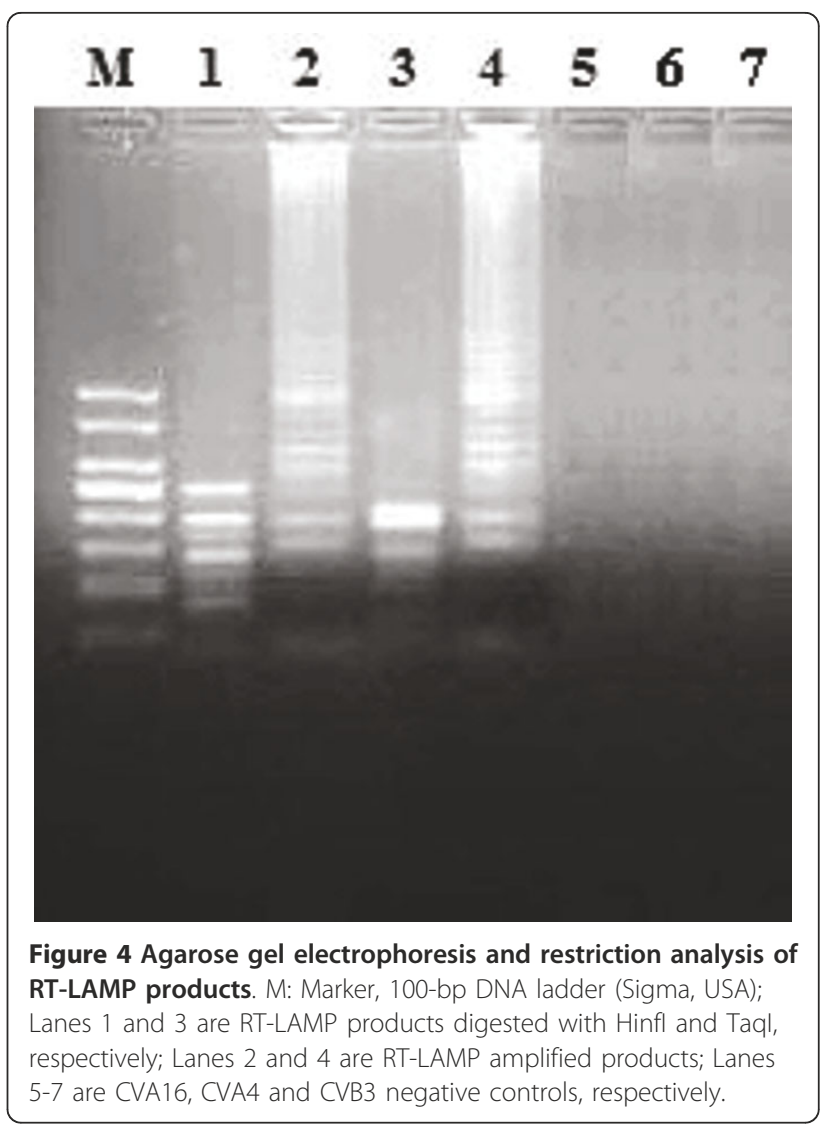

verified as positive EV71 infection. The positive rates of 93 pharyngeal swabs detected by RT-LAMP and PCR fluorescence probing assay were 44.1 and $41.9 \%$, respectively, and the positive rates of 20 vesicular fluid swabs and 10 fecal samples detected by both methods were $60.0 \%$ and $50.0 \%$ (Table 2 ).

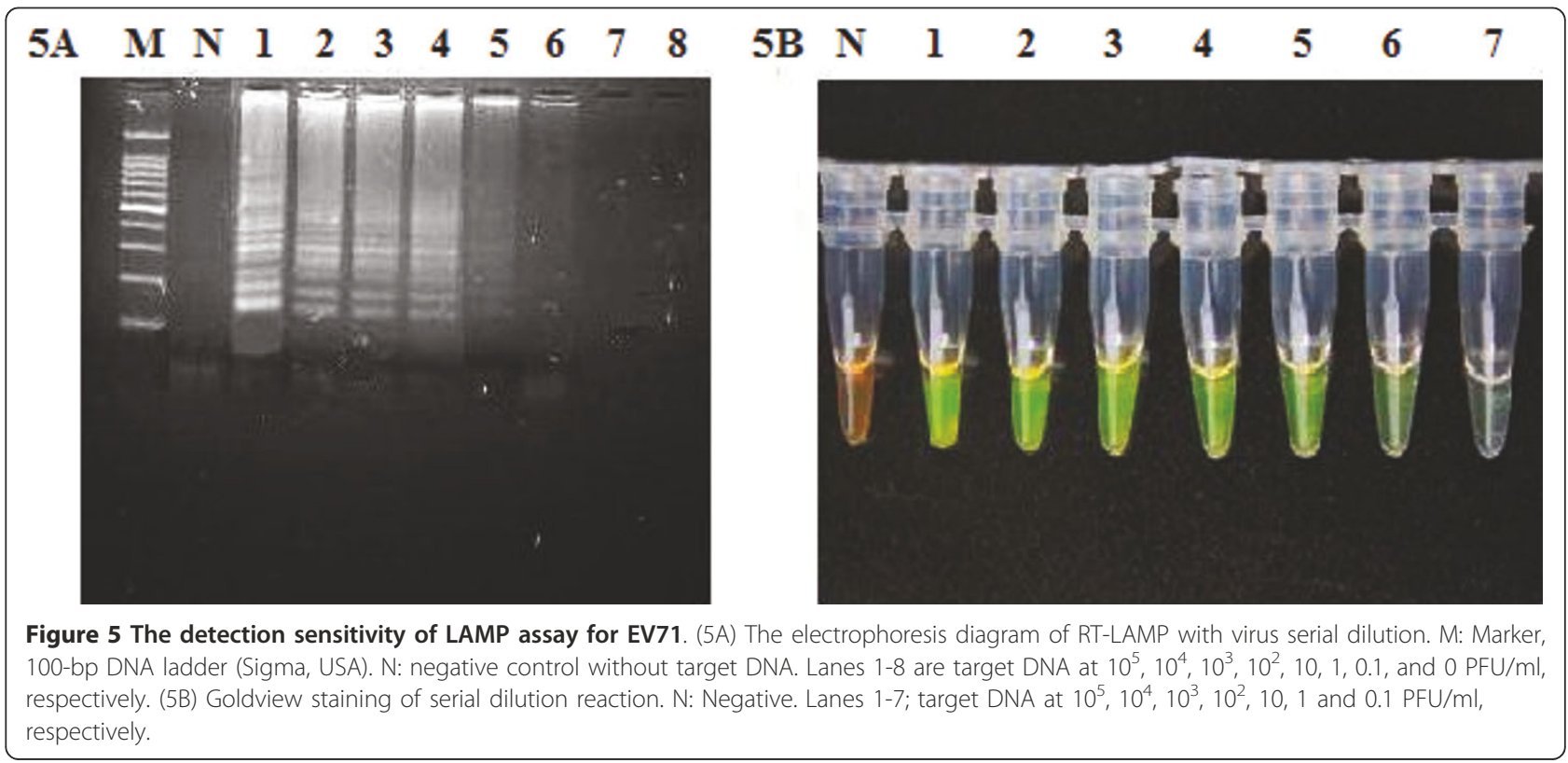




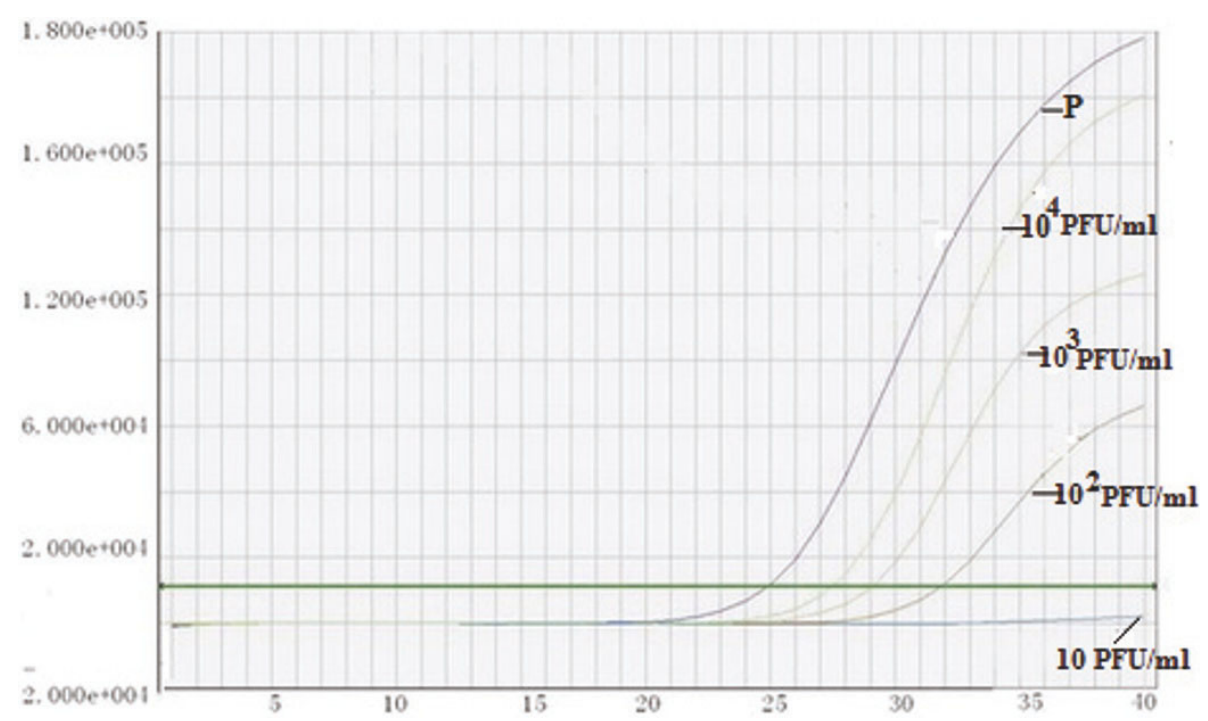

Figure 6 The detection sensitivity of PCR fluorescence probing assay. P: EV71 positive control; RNA samples $\left(10^{4} \mathrm{PFU} / \mathrm{ml}\right)$ with $10^{-1}-10^{-3}$ dilutions, respectively.

\section{Discussion}

Human enterovirus belongs to the RNA virus family Picornaviridae including polioviruses, type A coxsackieviruses, type B coxsackieviruses, echoviruses, and enterovirus types 68 to 71 (EV68-71) [15,27]. Due to the prevalence of EV71 infection, time-consuming viral culture and serological tests for EV71, it is important to develop fast, efficient and sensitive diagnostic reagents $[28,29]$. Although PCR technique has been widely used in the detection of infectious diseases and the real-time PCR assay has multiple advantages such as faster quantitative measurement, lower contamination rate, higher sensitivity, higher specificity and easier standardization, these nucleic acid amplification methods require highprecision instruments and skilled technicians [30,31].

LAMP is a nucleic acid amplification method that relies on autocycling strand displacement DNA synthesis completed by Bst DNA polymerase. Because of high sensitivity and specificity coupled with the requirements for only a water bath and endpoint detection using a color-change reaction visible with the naked eye [32-34], LAMP assay has been applied for the analysis of various infections from Mycobacterium tuberculosis, Norovirus, Human papillomavirus, Cytomegalovirus, and Human immunodeficiency virus [20,35-38].

In this study, a one-step and simple assay for EV71 virus without requirement of thermal cycling can be completed within $60 \mathrm{~min}$ in a single tube containing the mixture of buffer, primers, reverse transcriptase and Bst DNA polymerase. In order to ensure its accuracy and reliable amplification, it is very important to optimize the reaction temperature. At the optimal reaction temperature of $60^{\circ} \mathrm{C}$, clear bands of amplified products were observed in gel electrophoresis.

Similarly, the optimal reaction time, magnesium and betaine concentrations were achieved. Except for amplified products detected by agarose gel electrophoresis as described above, two alternative detection methods could also be used for the evaluation. 1) Turbidity: the accumulation of magnesium pyrophosphate, a by-product of amplified DNA, results in the increase of the turbidity in samples. The turbidity in samples was evaluated by visual inspection. However, when the virus content of samples is low, it is difficult to observe the

Table 2 Comparison of 123 specimens from suspicious HFMD patients were analyzed by RT-LAMP and PCR fluorescence probing assay

\begin{tabular}{cccccc}
\hline Specimen type & Number of samples & \multicolumn{2}{c}{ RT-LAMP } & \multicolumn{2}{c}{ PCR fluorescence probing } \\
\cline { 2 - 6 } & & $41(44.1)$ & $52(55.9)$ & Positive (\%) & Negative (\%) \\
\hline Pharyngeal swabs & 93 & $12(60.0)$ & $8(40.0)$ & $12(60.0)$ & $54(58.1)$ \\
Vesicular fluids & 20 & $5(50.0)$ & $5(50.0)$ & $5(50.0)$ & $5(40.0)$ \\
Fecal samples & 10 & $58(47.2)$ & $65(52.8)$ & $56(45.5)$ & $67(54.4)$ \\
Total & 123 & & &
\end{tabular}

*Positive: EV71 positive samples; \#Negative: EV71 negative samples. 
turbidity by visual inspection. 2) Fluorescence change: GoldView staining was used for evaluating the amplification. Samples with the fluorescence conversion from orange to green or from orange to red under an UV handheld lamp at a $254 \mathrm{~nm}$ were considered as the positive and negative, respectively. Different from traditional ethidium bromide (EB) for detecting double-stranded DNA, single-stranded DNA, and RNA, Goldview staining can emit green fluorescence when bound to dsDNA and red fluorescence when bound to ssDNA or RNA. However, compared to EB with strong mutagen, Goldview has relatively fewer mutations and higher safety.

Particularly, similar clinical symptoms in infections caused by EV71 and CVA16 with high similarity in nucleotide sequences were observed. Therefore, frequent mis-diagnosis between EV71 and CVA16 infections was happened due to the difficulty in distinguishing both viruses [39]. However, exact nucleotide sequences of RT-LAMP products can be predicted from target DNA and primers. Thus, it is possible to predict the digestion outcome of the samples with restriction enzymes at the specific recognition sites. In the present study, the specific products could be digested by HinfI and TaqI restriction enzymes to result in a series of bands in agarose gel electrophoresis, in contrast, non-specific products could not be detected due to without digestion. Therefore, RT-LAMP assay can provide high specificity for the detection of EV71.

The sensitivity of RT-LAMP assay for EV71 detection was determined by testing serial 10-fold dilutions of virus with a detection limit of $1 \mathrm{PFU} / \mathrm{ml}$. In order to evaluate the reliability of RT-LAMP, 123 suspicious samples were simultaneously detected by PCR fluorescence probing assay and RT-LAMP. Both test systems had $98.4 \%$ similarity without significant difference. With a detection limit of $1 \mathrm{PFU} / \mathrm{ml}$, RT-LAMP assay exhibited much higher sensitivity than PCR fluorescence probing assay, as well as virus culture. Between two positive samples identified by RT-LAMP but PCR fluorescence probing assay negative, only one sample was verified as EV71 infection by virus culture and indirect immunofluorescence test, which further confirmed the higher sensitivity of RT-LAMP assay.

Besides pharyngeal, vesicular fluid and stool, RTLAMP can be used to detect other samples such as cerebrospinal fluid, etc. However, the application of RTLAMP in these samples needs to be further explored to provide more evidences in the early diagnosis of EV71 infection.

\section{Conclusions}

RT-LAMP assay is characteristics of high sensitivity, rapid detection, high specificity and low cost, which has considerable potentials for the detection of EV71 infection in the primary health care institutions, field environments or developing countries.

\section{Acknowledgements}

We thank Guanghua Luo and Yuehua Feng for their help in the LAMP assay and electrophoresis analysis.

\section{Author details}

${ }^{1}$ Department of Clinical Laboratory, The Third Affiliated Hospital of Suzhou University, No. 185 Juqian street, Changzhou, Jiangsu 213003, P. R. China.

${ }^{2}$ Wuxi Clone Gen-Tech Institute, No. 26 Fenghua Road, Wuxi, Jiangsu 214026, P. R. China.

\section{Authors' contributions}

WS conceived the study, carried out the molecular genetic studies, analyzed the data and drafted the manuscript; $\mathrm{KL}$ and $\mathrm{YJ}$ participated in the design and carrying out specimen collection; QJ performed PCR-Fluorescence probing assay, agar gel electrophoresis and analyzed the data; MS and ZM helped coordinate the investigation and participated in LAMP assay. All authors contributed to the study and have read and approved the final manuscript.

\section{Competing interests}

The authors declare that they have no competing interests.

Received: 5 March 2011 Accepted: 18 July 2011 Published: 18 July 2011

\section{References}

1. Wu Y, Yeo A, Phoon MC, Tan EL, Poh CL, Quak SH, Chow VT: The largest outbreak of hand; foot and mouth disease in Singapore in 2008:the role of enterovirus 71 and coxsackievirus A strains. Int J Infect Dis 2010, 14: e1076-1081.

2. Solomon $T$, Lewthwaite $P$, Perera $D$, Cardosa MJ, McMinn $P$, Ooi MH: Virology, epidemiology, pathogenesis, and control of enterovirus 71. Lancet Infect Dis 2010, 10:778-790.

3. Davia JL, Bel PH, Ninet VZ, Bracho MA, Gonzalez-Candelas F, Salazar A, Gobernado M, Bosch IF: Onychomadesis outbreak in Valencia, Spain associated with hand, foot, and mouth disease caused by enteroviruses. Pediatr Dermatol 2011, 28:1-5.

4. Zhou F, Kong F, Wang B, McPhie K, Gilbert GL, Dwyer DE: Molecular characterization of enterovirus 71 and coxsackievirus A16 using the 5 'untranslated region and VP1 region. Journal of medical microbiology 2011, 60:349-358.

5. Schuffenecker I, Mirand A, Antona D, Henquell C, Chomel Jر, Archimbaud C, Billaud G, Peigue-Lafeuille H, Lina B, Bailly JL: Epidemiology of human enterovirus 71 infections in France, 20002009. J Clin Virol 2010, 50:50-56.

6. Schmidt NJ, Lennette $\mathrm{EH}, \mathrm{Ho} H \mathrm{H}$ : An apparently new enterovirus isolated from patients with disease of the central nervous system. J Infect Dis 1974, 129:304-309.

7. Huang SW, Hsu YW, Smith DJ, Kiang D, Tsai HP, Lin KH, Wang SM, Liu CC, Su IJ, Wang JR: Reemergence of enterovirus 71 in 2008 in taiwan: dynamics of genetic and antigenic evolution from 1998 to 2008. J Clin Microbiol 2009, 47:3653-3662.

8. Ma E, Lam T, Chan KC, Wong C, Chuang SK: Changing epidemiology of hand, foot, and mouth disease in Hong Kong, 2001-2009. Jpn J Infect Dis 2010, 63:422-426.

9. Tee KK, Takebe $Y$, Kamarulzaman A: Emerging and re-emerging viruses in Malaysia, 1997-2007. Int J Infect Dis 2009, 13:307-318.

10. Chan KP, Goh KT, Chong CY, Teo ES, Lau G, Ling AE: Epidemic hand, foot and mouth disease caused by human enterovirus 71, Singapore. Emerg Infect Dis 2003, 9:78-85.

11. Zhu Z, Zhu S, Guo X, Wang J, Wang D, Yan D, Tan X, Tang L, Zhu H, Yang $Z$, Jiang $X$, Ji $Y$, Zhang $Y, X u$ W: Retrospective seroepidemiology indicated that human enterovirus 71 and coxsackievirus A16 circulated wildly in central and southern China before large-scale outbreaks from 2008. Virol J 2010, 7:300

12. Mao LX, Wu B, Bao WX, Han FA, Xu L, Ge QJ, Yang J, Yuan ZH, Miao CH, Huang $X X$, Zhang $C$, Xu H: Epidemiology of hand, foot, and mouth 
disease and genotype characterization of Enterovirus 71 in Jiangsu, China. J Clin Virol 2010, 49:100-104

13. Zhang Y, Zhu Z, Yang W, Ren J, Tan X, Wang Y, Mao N, Xu S, Zhu S, Cui A, Yan D, Li Q, Dong X, Zhang J, Zhao Y, Wan J, Feng Z, Sun J, Wang S, Li D, Xu W: An emerging recombinant human enterovirus 71 responsible for the 2008 outbreak of hand foot and mouth disease in Fuyang city of China. Virol J 2010, 7:94.

14. Komatsu H, Shimizu Y, Takeuchi Y, Ishiko H, Takada H: Outbreak of severe neurologic involvement associated with Enterovirus 71 infection. Pediatr Neurol 1999, 20:17-23.

15. Shah VA, Chong CY, Chan KP, Ng W, Ling AE: Clinical characteristics of an outbreak of hand, foot and mouth disease in Singapore. Ann Acad Med Singapore 2003, 32:381-387.

16. Chen TC, Chen GW, Hsiung CA, Yang JY, Shih SR, Lai YK, Juang JL: Combining multiplex reverse transcription-PCR and a diagnostic microarray to detect and differentiate enterovirus 71 and coxsackievirus A16. J Clin Microbiol 2006, 44:2212-2219.

17. Tan EL, Yong LL, Quak SH, Yeo WC, Chow VT, Poh CL: Rapid detection of enterovirus 71 by real-time TaqMan RT-PCR. J Clin Virol 2008, 42:203-206.

18. Xiao XL, He YQ, Yu YG, Yang H, Chen G, Li HF, Zhang JW, Liu DM, Li XF, Yang $\mathrm{XQ}, \mathrm{Wu} \mathrm{H}$ : Simultaneous detection of human enterovirus 71 and coxsackievirus A16 in clinical specimens by multiplex real-time PCR with an internal amplification control. Arch Virol 2009, 154:121-125.

19. Notomi T, Okayama H, Masubuchi H, Yonekawa T, Watanabe K, Amino N, Hase T: Loop-mediated isothermal amplification of DNA. Nucleic Acids Res 2000, 28:E63.

20. Lee MF, Chen YH, Peng CF: Evaluation of reverse transcription loopmediated isothermal amplification in conjunction with ELISAhybridization assay for molecular detection of Mycobacterium tuberculosis. J Microbiol Methods 2009, 76:174-180.

21. Sun J, Najafzadeh MJ, Vicente V, Xi L, de Hoog GS: Rapid detection of pathogenic fungi using loop-mediated isothermal amplification, exemplified by Fonsecaea agents of chromoblastomycosis. J Microbiol Methods 2010, 80:19-24.

22. Parida MM, Santhosh SR, Dash PK, Tripathi NK, Saxena P, Ambuj S, Sahni AK, Lakshmana Rao PV, Morita K: Development and evaluation of reverse transcription-loop-mediated isothermal amplification assay for rapid and real-time detection of Japanese encephalitis virus. J Clin Microbiol 2006, 44:4172-4178.

23. Jiang T, Liu J, Deng YQ, Xu LJ, Li XF, Han JF, Cao RY, Qin ED, Qin CF: Development and evaluation of a reverse transcription-loop-mediated isothermal amplification assay for rapid detection of enterovirus 71. J Clin Microbiol 2011, 49:870-874.

24. Nix WA, Oberste MS, Pallansch MA: Sensitive, seminested PCR amplification of VP1 sequences for direct identification of all enterovirus serotypes from original clinical specimens. J Clin Microbiol 2006, 44:2698-2704

25. Kasahara T, Shioiri-Nakano K, Sugiura A: Virus plaque assay: effective detection of virus plaque forming cells at the early stage of lymphocyte activation by mitogen and alloantigen. Immunology 1979, 36:381-390.

26. Langlet J, Gaboriaud F, Gantzer C: Effects of $\mathrm{pH}$ on plaque forming unit counts and aggregation of MS2 bacteriophage. J Appl Microbiol 2007, 103:1632-1638.

27. Frydenberg A, Starr M: Hand, foot and mouth disease. Aust Fam Physician 2003, 32:594-595.

28. Van Doornum GJ, De Jong JC: Rapid shell vial culture technique for detection of enteroviruses and adenoviruses in fecal specimens: comparison with conventional virus isolation method. J Clin Microbiol 1998, 36:2865-2868.

29. Mizuta K, Aoki Y, Suto A, Ootani K, Katsushima N, Itagaki T, Ohmi A, Okamoto M, Nishimura H, Matsuzaki Y, Hongo S, Sugawara K, Shimizu H, Ahiko T: Cross-antigenicity among EV71 strains from different genogroups isolated in Yamagata, Japan, between 1990 and 2007. Vaccine 2009, 27:3153-3158.

30. Fout GS, Martinson BC, Moyer MW, Dahling DR: A multiplex reverse transcription-PCR method for detection of human enteric viruses in groundwater. Appl Environ Microbiol 2003, 69:3158-3164.

31. Jimenez-Clavero MA, Escribano-Romero E, Mansilla C, Gomez N, Cordoba L, Roblas N, Ponz F, Ley V, Saiz JC: Survey of bovine enterovirus in biological and environmental samples by a highly sensitive real-time reverse transcription-PCR. Appl Environ Microbiol 2005, 71:3536-3543.
32. Imai M, Ninomiya A, Minekawa H, Notomi T, Ishizaki T, Van Tu P, Tien NT, Tashiro M, Odagiri T: Rapid diagnosis of H5N1 avian influenza virus infection by newly developed influenza $\mathrm{H} 5$ hemagglutinin gene-specific loop-mediated isothermal amplification method. J Virol Methods 2007, 141:173-180.

33. Fukuta S, lida T, Mizukami Y, Ishida A, Ueda J, Kanbe M, Ishimoto Y: Detection of Japanese yam mosaic virus by RT-LAMP. Arch Virol 2003, 148:1713-1720.

34. Morishita S, Tani H, Kurata S, Nakamura K, Tsuneda S, Sekiguchi Y, Noda N: Real-time reverse transcription loop-mediated isothermal amplification for rapid and simple quantification of WT1 mRNA. Clin Biochem 2009, 42:515-520

35. Fukuda S, Takao S, Kuwayama M, Shimazu Y, Miyazaki K: Rapid detection of norovirus from fecal specimens by real-time reverse transcription-loopmediated isothermal amplification assay. J Clin Microbiol 2006, 44:1376-1381.

36. Hagiwara M, Sasaki H, Matsuo K, Honda M, Kawase M, Nakagawa H: Loopmediated isothermal amplification method for detection of human papillomavirus type 6, 11, 16, and 18. J Med Virol 2007, 79:605-615.

37. Reddy AK, Balne PK, Reddy RK, Mathai A, Kaur I: Development and evaluation of loop-mediated isothermal amplification assay for rapid and inexpensive detection of cytomegalovirus DNA in vitreous specimens from suspected cases of viral retinitis. J Clin Microbiol 2010 48:2050-2052.

38. Hosaka N, Ndembi N, Ishizaki A, Kageyama S, Numazaki K, Ichimura H: Rapid detection of human immunodeficiency virus type 1 group $\mathrm{M}$ by a reverse transcription-loop-mediated isothermal amplification assay. J Virol Methods 2009, 157:195-199.

39. Miao LY, Pierce C, Gray-Johnson J, DeLotell J, Shaw C, Chapman N, Yeh E, Schnurr D, Huang YT: Monoclonal antibodies to VP1 recognize a broad range of enteroviruses. J Clin Microbiol 2009, 47:3108-3113.

Pre-publication history

The pre-publication history for this paper can be accessed here: http://www.biomedcentral.com/1471-2334/11/197/prepub

\section{doi:10.1186/1471-2334-11-197}

Cite this article as: Shi et al:: Development and evaluation of reverse transcription-loop-mediated isothermal amplification assay for rapid detection of enterovirus 71. BMC Infectious Diseases 2011 11:197.

\section{Submit your next manuscript to BioMed Central and take full advantage of:}

- Convenient online submission

- Thorough peer review

- No space constraints or color figure charges

- Immediate publication on acceptance

- Inclusion in PubMed, CAS, Scopus and Google Scholar

- Research which is freely available for redistribution

Submit your manuscript at www.biomedcentral.com/submit
C BioMed Central 